\title{
The effectiveness of animal physiology practical book based on guided inquiry model
}

Rina Widiana a,1,*, Diana Sussanti a,2, Silvi Susanti a,3, Ramadhan Sumarmin ${ }^{\text {b,4 }}$

a Biology Education Study Program, STKIP PGRI Sumatera Barat, Jl. Gunung Pangilun, Padang, West Sumatera 25000, Indonesia

${ }^{b}$ Biology Department, Faculty of Mathematics and Natural Sciences, Universitas Negeri Padang, Jl. Prof. Dr. Hamka, Air Tawar,

Padang, West Sumatera 25131, Indonesia

${ }^{1}$ rinaroesdi68@gmail.com *, 2 ramadhan-sum@fmipa.unp.ac.id , ${ }^{3}$ dianasusantimpd@yahoo.co.id, ${ }^{4}$ silvisusanti@gmail.com

* Corresponding author

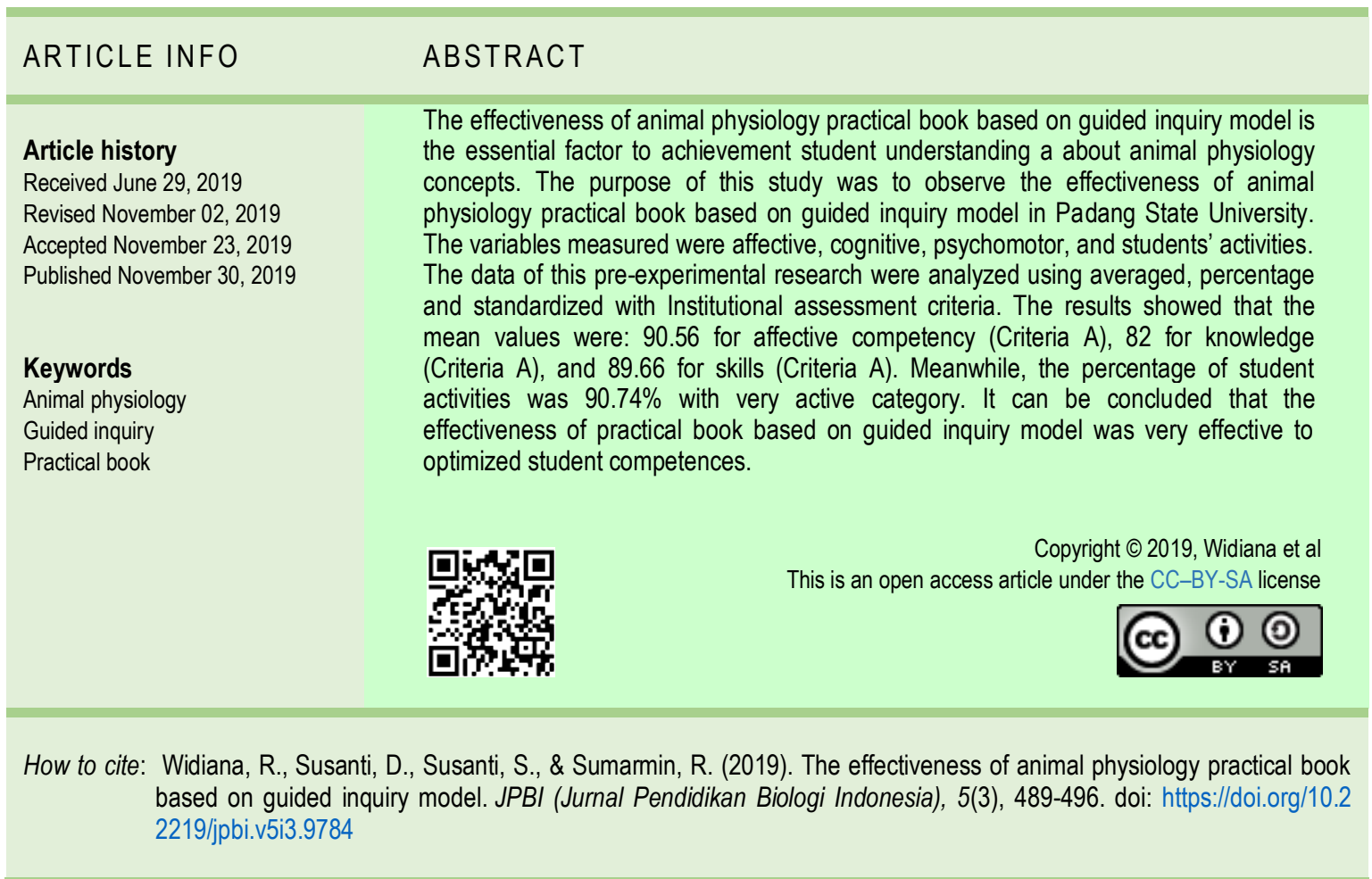

\section{INTRODUCTION}

Submission of material physiology of animals has only used power point media and printed book sources. There are no special learning resources that are able to direct the achievement of the course. Media education is very important to support the achievement of educational goals (Koksal \& Berberoglu, 2014; Mulyana, Rusdi, \& Vivanti, 2018). Power point designed for this is from a variety of sources of printed books, but there is still a shortage because there are few things more specific in animal physiology college student cannot be expressed in the learning process. While the practical guide used as a complement to students 'understanding of lectures has also not been able to provide maximum results for students' understanding. Practical guide used only consists of the introduction of material, work steps and questions. This has not been able to provide benefits as a good teaching material. One of the roles of teaching materials according to includes the role for teachers, students, in classical, individual, and group learning (Sukariasih, Saputra, Ikhsan, Sejati, \& Nisa, 2019). 
As teaching material that is able to provide skills and enhance student understanding, the practical guiding component used so far is not feasible. The correct guiding component of the practicum is to have an introduction, practicum objectives, basic theory, tools and materials, work steps / procedures, data / results of observations, discussion, questions and conclusions (Faradilla, Hasan, \& Sulastri, 2018; Hasibuan, Saragih, \& Amry, 2018; Widiana, Sumarmin, Susanti, \& Susanti, 2019). Because of the lack of components in the practicum guide, students are unable to find out for themselves the knowledge that is being discussed. Practical guide for animal physiology has been developed to the level of effectiveness in the university itself with the results of activities that are very effective and learning outcomes are at level B for three domains of assessment, namely affective, cognitive and psychomotor, besides the activity of developing the stage develop guide which is also done with very effective criteria (Widiana, Sumarmin, Susanti, \& Susanti, 2018)

Experimentation is a complex problem-solving process. In biology lessons, experiments involve creative thinking and open discovery; however, they still require some degree of instructional guidance (Großmann \& Wilde, 2019). Practical guides that have been developed are guided inquiry based. Guided inquiry enables students to identify problems, define hypotheses, formulate problems, collect data, verify results, and generalize conclusions (Choirunnisak, Ibrahim, \& Yuliani, 2018; Matthew \& Kenneth, 2013). The advantages of guided inquiry include lecturers who do not just let go of student activities, so students are able to take part in the activities being carried out well without thinking about the level of ability of students. Thus according to Irwan, Maridi, \& Dwiastuti, (2019) guided inquiry learning is estimated to be used as an alternative in learning. In order for a practical guide to be used more broadly, then continued the disseminate research at Padang State University. Research on the development of practical guidance based on guided inquiry approaches has been carried out. According to Suprianto, Kholida, \& Andi, (2017) the development of a basic physics practicum guide 1 was based on guided inquiry to improve students' hard skills and soft skills in good criteria. Likewise with the research Repdayanti, Mawardi \& Oktavia, (2018) the guided inquiry-based student worksheet has been valid, practical, and effectively used in the chemistry learning process at the rate material of the reaction. Meanwhile according to Citrawathi \& Adnyana, (2018) learning using question-based inquiry module on human's digestion system has a significant effect on increasing science process and student learning process. The development of guided inquiry-based learning devices on photosynthesis and respiration matter was feasible to train students literacy science skills (Choirunnisak et al., 2018).

Various practical book development studies have been carried out, unfortunately there is still not much going through the dissemination stage. This research is the disseminate stage of the four $\mathrm{D}$ model and is a continuation of the develop stage (Widiana et al., 2019; Widiana et al., 2018).The purpose of this study was to see the results of disseminate at Padang State University in terms of affective, cognitive, psychomotor, activity using guided inquiry-based animal physiology practicum.

\section{METHOD}

This research is a development study using Four-D models. The stage to be examined is the disseminate stage. This disseminate stage looks at student learning outcomes in the realm of attitudes, knowledge and skills as well as student activities while using physiology practicum guides based on guided inquiry. The research data consisted of the effectiveness values of practicum guides in the formation of attitudes, cognitive, psychomotor and student activities. Data was taken at 3 practicum meetings. Aspects of attitude include discipline, responsibility and coordination, cognitive includes pre-test and post-test scores, psychomotor includes preparation, implementation and reporting, and activities include practicum and writing practical result.

This research was conducted at Universitas Negeri Padang 2018/2019 academic year. The sample in this study was 30 students participating in animal physiology practicum in the even semester 2018/2019 in the Biology Education Study Program, Faculty of Mathematics and Natural Sciences (Fakultas Matematika dan IImu Pengetahuan Alam/FMIPA) Universitas Negeri Padang. Data colection of attitude, psychomotor and activity using questionnaires using a modified questionnaire from (Susanti, Sri, Fitriani, Riandi, \& Supriatno, 2018), and cognitive data using written tests in the form of assays. Data analyses of attitude, psychomotor, and activity in the form of percentages as shown in Formula 1 (Riduwan, 2006).

Percentage Value $=\frac{\text { Score obtained } \square}{\text { Maximum score of }} \times 100 \%$ 
Analysis of cognitive data in an average form and processing assessment of knowledge obtained by students using learning completeness formula (Trianto, 2009), as shown in Formula 2.

$\mathrm{KB}=\frac{T}{T t} \times 100$

Where KB: Learning completeness; T: Number of scores obtained by students; and Tt: Total score.

The level of success of student learning using the following standards of attitude, knowledge and psychomotor assessment, can be seen in Table 1.

Table 1. The level of success of student learning

\begin{tabular}{cc}
\hline Value & Conversion \\
\hline $81-100$ & $\mathrm{~A}$ \\
$66-80$ & $\mathrm{~B}$ \\
$56-65$ & $\mathrm{C}$ \\
$46-55$ & $\mathrm{D}$ \\
$\leq 45$ & $\mathrm{E}$ \\
\hline
\end{tabular}

Source: (STKIP PGRI Sumatera Barat, 2017)

The classification of learning activities using the modified (Riduwan, 2006). Classification is shown in Table 2.

Table 2. Criteria for student learning activities

\begin{tabular}{cc}
\hline Achievement Level (\%) & Conversion \\
\hline $81-100$ & Very good / very effective \\
$61-80$ & good / effective \\
$41-60$ & Sufficient / quite effective \\
$21-40$ & Poor / less effective \\
$1-20$ & Not good / ineffective \\
\hline
\end{tabular}

\section{RESULTS AND DISCUSSION}

The results of evaluating the effectiveness of the use of animal physiology practicum based on guided inquiry approaches to the formation of attitudes, cognitive and student activities. Guided inquiry-based practicum guides have been used for 3 meetings. The results of the analysis of the assessment of attitudes, knowledge, motivational skills and student learning activities can be seen in the following Figure 1.

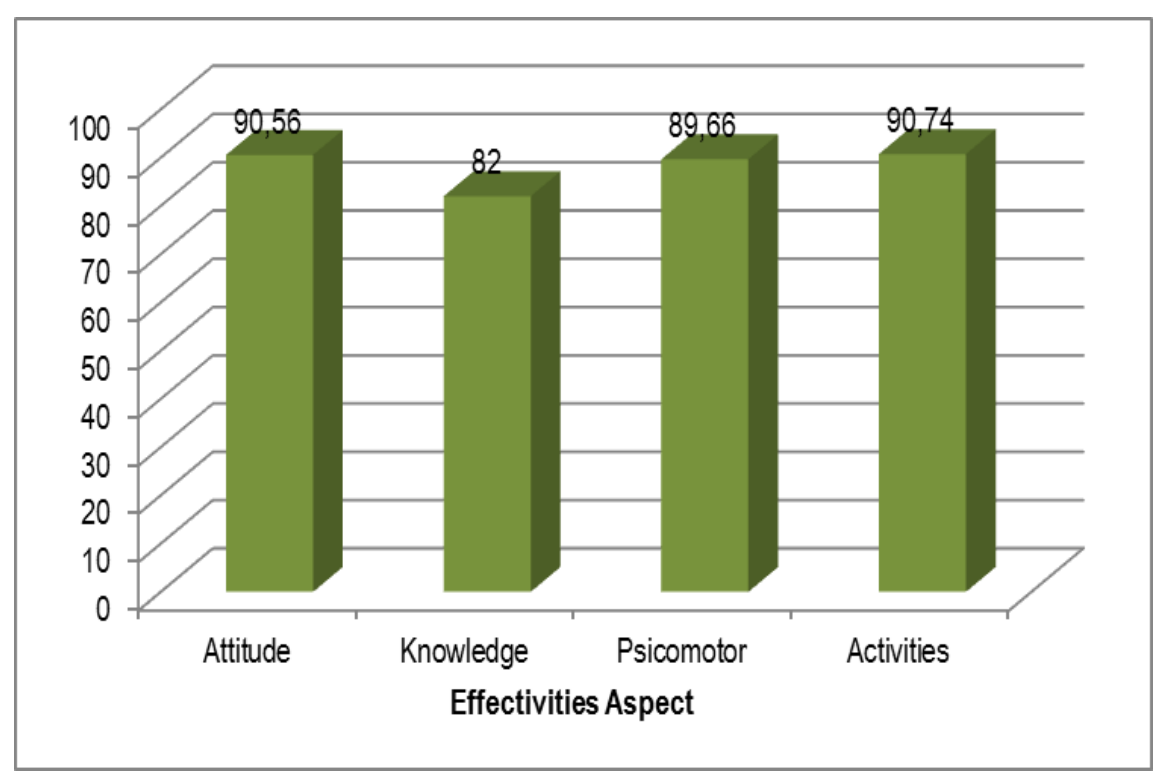

Figure 1. Average effectiveness value in each aspect 
Based on Figure 1, the effectiveness value of the use of practicum guides based on guided inquiry approaches in animal physiology courses in affective formation is $90.56 \%$, psychomotor is $89.66 \%$, activity is $90.74 \%$ with very effective criteria and the average value of knowledge is 82 with the predicate A. These results indicate that the guideline of animal physiology practicum based on guided inquiry approach is effectively used in the implementation of practicum in the Biology Education Study Program-UNP. The ability of students in constructing answers and thinking intelligently in solving problems, developing skills in understanding concepts, building a sense of responsibility and communicating concepts found can be trained through guided inquiry (Stender, Schwichow, Zimmerman, \& Härtig, 2018; Sukariasih et al., 2019). The guided inquiry was a learning model that was able to hone students' ability worked scientifically through investigation with coherent stepped so as facilitated students in carrying out practicum (Repdayanti et al., 2018; Widyaningrum \& Wijayanti, 2018). The results of the assessment using guided inquiry-based practicum guides fall into the very good category. Attitude assessment, the observed aspects are discipline, responsibility and cooperation. The average value of each meeting aspect of this attitude can be seen in Table 3.

Table 3. Average effectiveness value for each indicator of attitude assessment

\begin{tabular}{lccc}
\hline \multicolumn{1}{c}{ Aspects } & \multicolumn{3}{c}{ Meeting } \\
\cline { 2 - 4 } & $\mathbf{1}$ & $\mathbf{2}$ & $\mathbf{3}$ \\
\hline Discipline & 86.21 & 90.74 & 91.67 \\
Responsibility and cooperation & 88.79 & 92.59 & 93.3 \\
\hline Average & $\mathbf{8 7 . 5}$ & $\mathbf{9 1 6 6 5}$ & $\mathbf{9 2 4 8 5}$ \\
\hline
\end{tabular}

Based on Table 3, average assessment contained each meeting, the assessment of progress even in category A. From each the meeting, it seems that students have been careful in observing and understanding all parts of the practical guide, following all the instructions contained in the practical guide with discipline, working in accordance with the stages of work steps and time allocated, carefully and skillfully using tools and materials and pay attention to work order and safety during practical activities. In addition, students also appear to collaborate in preparing and compiling practical tools and materials according to the stages of work before practicum begins, participating in collaboration in carrying out each step of the work step, collaborating in understanding problems and formulating hypotheses, collaborating in seeking theoretical foundations and collecting, analyze data and interpret data and collaborate in developing discussions and conclusions, preparing presentation materials and reflecting.

The guided inquiry activities phase contained in practical guides can be carried out by students, with lecturers or assistants as facilitators. It makes student interaction in learning better. The scientific attitude of students learning with inquiry builds better social interaction (Sitorus \& Edi, 2017). In addition, guided inquirybased animal physiology guides are able to guide students to thorough, responsibility and cooperation with the stages that already exist in the guide. Students are able to do research repeatedly and ongoing guidance will be an advantage after learning inquiry (Agustanti, 2012). The assessment of knowledge, each student performs pretest and posttest activities at each meeting. At the final meeting, students are given a test according to the material that has been done Structured inquiry learning can not only lead to sustainable knowledge but also reveal long-term acquisition of knowledge as positively linked to students' effort during the inquiry lesson (Schmid \& Bogner, 2015). The details of the assessment of knowledge that has been passed by students are in the following Table 4.

Table 4. Average cognitive values for pretest and posttest and for each aspect of attitude analysis of knowledge assessment

\begin{tabular}{|c|c|c|c|c|c|c|}
\hline \multicolumn{6}{|c|}{ Meeting } & \multirow{3}{*}{ Final test } \\
\hline \multicolumn{2}{|c|}{1} & \multicolumn{2}{|c|}{2} & \multicolumn{2}{|c|}{3} & \\
\hline Pretest & Posttest & Pretest & Posttest & Pretest & Posttest & \\
\hline $43.01(E)$ & 69.73 (B) & $59.64(\mathrm{C})$ & $78.72(\mathrm{~B})$ & $64.67(\mathrm{C})$ & $85.33(\mathrm{~A})$ & $82(\mathrm{~A})$ \\
\hline
\end{tabular}

Based on Table 4. Assessment looks improvement of student learning outcomes for each meeting. The first meeting with an average pretest score was still in category $E$ when the posttest after using a guided inquiry-based guide increased to $B$. At the second meeting the value of pretest with category $C$ had increased from the first meeting, while the posttest value with category B looked the same as the first meeting but the average increases from the first meeting. As for the third meeting of the pretest results are still at $C$ category and the average assessment increase from the first meeting and the second, to posttest a category. It's higher 
than the first and second meetings. The final test results showed that students using guided inquiry-based practicum guides increased with value $A$. This shows that guided inquiry-based practicum guides can improve student learning outcomes and increase students' understanding lecture on animal physiology.

Focuses students' attention on a particular aspect of their engagement and exploration experiences and provides opportunities to demonstrate their conceptual understanding, process skills, or behaviors (Abdi, 2014). Guided inquiry learning and scientific performance influenced learning outcomes, because students are given the opportunity to solve their own problems and studied independently based on problems (Mulyana et al., 2018; Ningsih \& Said, 2018; Sardin, 2015; Sukariasih et al., 2019). The application of guided inquiry can improve students' scientific attitudes and analytical skills, because students experience direct experience with material objects. (Niana, Sarwanto, \& Ekawati, 2016; Sukariasih et al., 2019). Repetition of systematic and scientific thinking skills is an important ability for students to continue learning inquiry (Boaventura \& Faria, 2015). Build knowledge and understanding of how a scientist works is focused on student Inquiry activities (Fikri, Ismah, \& Paidi, 2018; Sitorus \& Edi, 2017). Thus guided inquiry can help improve student learning outcomes. The results of the skills assessment analysis for each meeting can be seen in Table 5.

Table 5. Average effectiveness value for each indicator of psicomotor analysis of results of skills assessment

\begin{tabular}{lccc}
\hline & Aspect & \multicolumn{3}{c}{ Meeting } \\
\cline { 2 - 4 } & $\mathbf{1}$ & $\mathbf{2}$ & $\mathbf{3}$ \\
\hline Preparation & 80.17 & 92.59 & 90 \\
Implementation & 83.26 & 93.52 & 90.83 \\
Reporting & 87.93 & 94.44 & 94.17 \\
\hline Average & $\mathbf{8 3 . 7 9}$ & $\mathbf{9 3 . 5 2}$ & $\mathbf{9 1 . 6 7}$ \\
\hline
\end{tabular}

The skills assessment analysis that has been done there is an increase in skills possessed by students for each meeting (Table 5). The skill assessment range is in category A but the average of each meeting has increased. If seen from the indicator of the assessment, it is seen that students make preparation, implementation and practical reporting. For the preparation stage (preparing tools, materials and understanding the work steps in the practicum guide), students have prepared complete practicum tools and materials according to practical needs, besides the tools and materials also look well organized and understand the work steps before the lab starts. At the implementation stage (carrying out and retrieving data) students have been skilled in using the tools and materials appropriately according to their functions, students have also carried out activities according to the instructions in the practical guide carefully, thoroughly and sequentially, completing all work according to time allocation and maintaining work security.

At the reporting stage (processing and analyzing data and reporting the results of lab work), it appears that students have been able to display, process, analyze and interpret data, conclude the results and arrange into the form of lab reports. Guided inquiry model with starter experiment approach in teaching science process skills of the students is effective, because it gives students a complex thinking space (Wardani \& Djukri, 2019). So that by using a guided inquiry-based practicum guide, it can train students to find and solve several problems with the skills they have and guided inquiry stages that are in the guide when in their small group (Walker \& Warfa, 2017). Accordance with the opinion Students work in small groups in the classroom or in the laboratory in an instructional module that presents information or data, followed by questions that lead are designed to guide students towards the formulation of conclusions (Khasanah, Susilaningsih, \& Nuswowati, 2017). Because in guided inquiry, students design and organize their own experiments (Fang et al., 2016). Inquiry learning affected student performance on the written report for the practical activity. The effective way to enhance student understanding of physiological concepts and experimental processes, allowing for a more realistic experience of the scientific method and a more effective use of time in practical classes (Quiroga \& Choate, 2019). Student activities using a practical guide for each meeting can be seen in the following Table 6.

Table 6. Average effectiveness value for each indicator of activities student activity analysis

\begin{tabular}{|c|c|c|c|}
\hline \multirow{2}{*}{ Aspects } & \multicolumn{3}{|c|}{ Meeting } \\
\hline & 1 & 2 & 3 \\
\hline Practicum & 85.34 & 87.04 & 96.67 \\
\hline Writing practical results & 87.07 & 91.67 & 96.67 \\
\hline Average & 86.20 & 89.36 & 96.67 \\
\hline
\end{tabular}


Student learning activities increase for each meeting; activities observed during practicum include practicum and write the results of the laboratory (Table 6). At the stage of conducting the practicum, it was seen that students were able to identify the scope of the problems contained in the practical guide, plan and predict results, investigate and interpret to collect data, develop conclusions and reflections. Practicable inquiry learning also provide opportunities for students to control variables, design experiments, analyze results and interpret data that can train students to reason (Sundari, Pursitasari, \& Heliawati, 2017; Ural, 2016). Whereas to write the results of the practicum, students have sorted the presentation systematically, the results of the practicum have answered the practicum objectives formulated, the practicum results are in accordance with the content and students have used the correct wording. Guided inquiry-based animal physiology guides have been able to increase student activities in finding their own knowledge and making learning effective (Putra, Sumarmin, \& Violita, 2018). Accordance to Hidayah \& Lailiy, (2018) that learning with guided inquiry is more effective in the process of learning science. Inquiry is a learning model that is organized to help students and teachers develop an understanding of the processes of natural phenomena and social activities taking place more easily, Guided inquiry gives students more open opportunities, but the teacher's ability also influences the implementation of the approach (Bunterm et al., 2014; Susanti et al., 2018), and increase of hard skills and soft skill of students (Suprianto et al., 2017).

\section{CONCLUSION}

The guideline of Physiology practicum based on guided inquiry approach is effectively used to fulfill learning outcomes, including attitudes $90.56 \%$, psychomotor $89.66 \%$ and activity $90.74 \%$ with very effective criteria, and cognitive 82 with predicate A. Based on the results and discussion, it can be concluded that the effectiveness of practicum guides based on guided inquiry have very effective to approve the learning outcomes.

\section{ACKNOWLEDGMENT}

On this occasion the author would like to thank DRPM (Direktorat Riset dan Pengabdian Masyarakat or Directorate of Research and Community Engagement) of Ministry of Research and Technology of the Republic of Indonesia Year 2019 Grand, Biology Education Study Program STKIP PGRI Sumatera Barat, and Faculty of Mathematics and Natural Sciences Universitas Negeri Padang to support this research.

\section{REFERENCES}

Abdi, A. (2014). The effect of inquiry-based learning method on students' academic achievement in science course. Universal Journal of Educational Research, 2(1), 37-41. doi: https://doi.org/10.13189/ujer.2014 020104

Agustanti, T. H. (2012). Implementasi metode inquiry untuk meningkatkan hasil belajar biologi. Jurnal Pendidikan IPA Indonesia, 1(1), 16-20. doi: https://doi.org/10.15294/jpii.v1i1.2007

Boaventura, D., \& Faria, C. (2015). Science inquiry-based activities in elementary education: How to support teachers" practices? International Journal of Information and Education Technology, 5(6), 451-455. doi: https://doi.org/10.7763/ijiet.2015.v5.548

Bunterm, T., Lee, K., Ng Lan Kong, J., Srikoon, S., Vangpoomyai, P., Rattanavongsa, J., \& Rachahoon, G. (2014). Do different levels of inquiry lead to different learning outcomes? A comparison between guided and structured inquiry. International Journal of Science Education, 36(12), 1937-1959. doi https://doi.o $\mathrm{rg} / 10.1080 / 09500693.2014 .886347$

Choirunnisak, Ibrahim, M., \& Yuliani. (2018). The development of guided inquiry-based learning devices on photosynthesis and respiration matter to train science literacy skills. IOP Conference Series: Materials Science and Engineering, 296(1), 012002. doi: https://doi.org/10.1088/1757-899X/296/1/012002

Citrawathi, D. M., \& Adnyana, P. B. (2018). Question-based inquiry module can be to increase science process skills on the study of humans digestive system. Journal of Physics: Conference Series, 1116(5), 052016. doi: https://doi.org/10.1088/1742-6596/1116/5/052016

Fang, S. C., Hsu, Y. S., Chang, H. Y., Chang, W. H., Wu, H. K., \& Chen, C. M. (2016). Investigating the effects of structured and guided inquiry on students' development of conceptual knowledge and inquiry 
abilities: A case study in Taiwan. International Journal of Science Education, 38(12), 1945-1971. doi: https://doi.org/10.1080/09500693.2016.1220688

Faradilla, M., Hasan, M., \& Sulastri. (2018). The effectiveness of guided inquiry-based student worksheets on students' generic science skills. Journal of Physics: Conference Series, 1088, 1-7. doi: https://doi.org /10.1088/1742-6596/1088/1/012106

Fikri, A. A., Ismah, V., \& Paidi, P. (2018). Pengembangan perangkat pembelajaran model guided inquiry untuk meningkatkan creative thinking siswa. Thabiea : Journal of Natural Science Teaching, 1(1), 1-8. doi: https://doi.org/10.21043/thabiea.v1i1.3651

Großmann, N., \& Wilde, M. (2019). Experimentation in biology lessons: guided discovery through incremental scaffolds. International Journal of Science Education, 41(6), 759-781. doi: https://doi.org/10.1080/0950 0693.2019.1579392

Hasibuan, A. M., Saragih, S., \& Amry, Z. (2018). Development of learning materials based on realistic mathematics education to improve problem solving ability and student learning independence. International Electronic Journal of Mathematics Education, 14(1), 243-252. doi: https://doi.org/10.2933 3/iejme/4000

Hidayah, R., \& Lailiy, N. (2018). Guided inquiry model to promote science process skill students on acid-base. Proceedings of the Mathematics, Informatics, Science, and Education International Conference (MISEIC 2018), 157(January), 96-97. doi: https://doi.org/10.2991/miseic-18.2018.23

Irwan, I., Maridi, M., \& Dwiastuti, S. (2019). Developing guided inquiry-based ecosystem module to improve students' critical thinking skills. JPBI (Jurnal Pendidikan Biologi Indonesia), 5(1), 51-60. doi: https://doi. org/10.22219/jpbi.v5i1.7287

Khasanah, F., Susilaningsih, E., \& Nuswowati, M. (2017). Guided inquiry-based questions integrated practice worksheets design to improve laboratory skills and knowledge. Journal of Innovative Science Education, 6(2), 235-242. doi: https://doi.org/10.15294/JISE.V6I2.16625

Koksal, E. A., \& Berberoglu, G. (2014). The effect of guided-inquiry instruction on 6th grade Turkish students' achievement, science process skills, and attitudes toward science. International Journal of Science Education, 36(1), 66-78. doi: https://doi.org/10.1080/09500693.2012.721942

Matthew, B. M., \& Kenneth, I. O. (2013). A study on the effects of guided inquiry teaching method on students achievement in logic. International Researcher, 2(1), 135-140. Retrieved from http://iresearcher.org/133 -140 BAKKE M.MATTHEW gambia.pdf

Mulyana, S., Rusdi, R., \& Vivanti, D. (2018). The effect of guided inquiry learning model and scientific performance on student learning outcomes. Indonesian Journal of Science and Education, 2(1), 105109. doi: https://doi.org/10.31002/ijose.v2i1.596

Niana, R., Sarwanto, \& Ekawati, E. Y. (2016). The application of guided inquiry model on physic learning to improve scientific attitude and students' analysis ability. Proceeding The 2nd International Conference On Teacher Training and Education Sebelas Maret University, 2(1), 605-615. Retrieved from https://jurnal.uns.ac.id/ictte/article/view/7168

Ningsih, P., \& Said, I. (2018). Application of guided inquiry learning model with mind map toward students' learning outcomes in chemistry material: Reaction rate. Proceedings of the First Indonesian Communication Forum of Teacher Training and Education Faculty Leaders International Conference on Education 2017 (ICE 2017), (June), 586-589. doi: https://doi.org/10.2991/ice-17.2018.126

Putra, Z. A. Z., Sumarmin, R., \& Violita, V. (2018). Development of animal physiology practical guidance oriented guided inquiry for student of biology department. IOP Conference Series: Materials Science and Engineering, 335(1), 012087. doi: https://doi.org/10.1088/1757-899X/335/1/012087

Quiroga, M. D. M., \& Choate, J. K. (2019). A virtual experiment improved students' understanding of physiological experimental processes ahead of a live inquiry-based practical class. Advances in Physiology Education, 43(4), 495-503. doi: https://doi.org/10.1152/advan.00050.2019

Repdayanti, Mawardi, \& Oktavia, B. (2018). The development of student worksheets based on guided inquiry by class and laboratory activity for reaction rate material at the 11th grade in high school. International Journal of Progressive Sciences and Technologies, 8(2), 286-294. Retrieved from http://ijpsat.ijshtjournals. org/index.php/ijpsat/article/view/409/236

Riduwan, M. B. . (2006). Belajar mudah penelitian untuk guru-karyawan dan peneliti muda. Retrieved from https://scholar.google.com/scholar?hl=id\&as_sdt=0\%2C5\&q=MBA+Riduwan\&btnG=

Sardin, S. (2015). Perbandingan keefektifan pembelajaran guided inquiry dan problem solving ditinjau dari prestasi belajar peluang, kemampuan penalaran, dan sikap siswa terhadap matematika. 
PYTHAGORAS: Jurnal Pendidikan Matematika, 10(2), 189. doi: https://doi.org/10.21831/pg.v10i2.9158

Schmid, S., \& Bogner, F. X. (2015). Effects of students' effort scores in a structured inquiry Unit on long-term recall abilities of content knowledge. Education Research International, 2015, 1-11. doi: https://doi.org/1 $0.1155 / 2015 / 826734$

Sitorus, H. H., \& Edi, S. (2017). The influence of inquiry learning model on student's scientific attitudes in ecosystem topic at MTS. Daarul Hikmah Sei Alim (Islamic Junior High School) Asahan. International Journal of Humanities, Social Sciences and Education, 4(11), 170-175. doi: https://doi.org/10.20431/2 349-0381.0411020

Stender, A., Schwichow, M., Zimmerman, C., \& Härtig, H. (2018). Making inquiry-based science learning visible: the influence of CVS and cognitive skills on content knowledge learning in guided inquiry. International Journal of Science Education, 40(15), 1812-1831. doi: https://doi.org/10.1080/09500693.2 018.1504346

STKIP PGRI Sumatera Barat. (2017). Buku pedoman akademik penyelenggaraaan pendidikan tahun akademik 2017/2018. Retrieved from https://baak.stkip-pgri-sumbar.ac.id/assets/BUKU_PEDOMAN_AK ADEMIK_2017.pdf

Sukariasih, L., Saputra, I. G. P. E., Ikhsan, F. A., Sejati, A. E., \& Nisa, K. (2019). Improving the learning outcomes of knowledge and inquiry skill domain on third grade students of SMP Negeri 14 Kendari through the guided inquiry learning model assisted by ccience kit. Geosfera Indonesia, 4(2), 175. doi: https://doi.org/10.19184/geosi.v4i2.10097

Sundari, T., Pursitasari, I. D., \& Heliawati, L. (2017). Pembelajaran inkuiri terbimbing berbasis praktikum pada topik laju reaksi. Pendidikan Sains Pascasarjana Universitas Negeri Surabaya, 6(2), 1340-1347. Retrieved from https://repository.unpak.ac.id/tukangna/repo/file/files-20181226022944.pdf

Suprianto, S., Kholida, S. I., \& Andi, H. J. (2017). Panduan praktikum fisika dasar 1 berbasis guided inquiry terhadap peningkatan hard skills dan soft skills mahasiswa. Momentum: Physics Education Journal, 1(2), 122. doi: https://doi.org/10.21067/mpej.v1i2.2073

Susanti, D., Sri, L. Y., Fitriani, V., Riandi, \& Supriatno, B. (2018). Effectiveness of $f$ the practical handbook based on problem based learning. International Journal of Progressive Sciences and Technologies, 10(1), 67-70. Retrieved from http://repo.stkip-pgri-sumbar.ac.id/id/eprint/3580/

Trianto. (2009). Mendesain model pembelajaran inovatif progresif (1st ed.). Retrieved from https://scholar.google.com/scholar?hl=id\&as_sdt=0\%2C5\&q=Alfabeta.+Trianto\%2C+2009.+Mendesain +Model+Pembelajaran+Inovatif-Progresif\&btnG=

Ural, E. (2016). The effect of guided-inquiry laboratory experiments on science education students' chemistry laboratory attitudes, anxiety and achievement. Journal of Education and Training Studies, 4(4), 217227. doi: https://doi.org/10.11114/jets.v4i4.1395

Walker, L., \& Warfa, A. R. M. (2017). Process oriented guided inquiry learning (POGIL®) marginally effects student achievement measures but substantially increases the odds of passing a course. PLOS ONE, 12(10), 1-17. doi: https://doi.org/10.1371/journal.pone.0186203

Wardani, I., \& Djukri, D. (2019). Teaching science process skill using guided inquiry model with starter experiment approach: An experimental study. JPBI (Jurnal Pendidikan Biologi Indonesia), 5(2), 277284. doi: https://doi.org/10.22219/jpbi.v5i2.8429

Widiana, R., Sumarmin, R., Susanti, D., \& Susanti, S. (2019). The practicality of practicum guidance based guided inquiry approach on animals physiology course. Journal of Physics: Conference Series, 1157(2). doi: https://doi.org/10.1088/1742-6596/1157/2/022077

Widiana, Rina, Sumarmin, R., Susanti, S., \& Susanti, D. (2018). The effectiveness and implementation of guiding practical based guided inquiry to improving learning outcomes on animal physiology. International Journal of Progressive Sciences and Technologies, 10(1), 126-133. Retrieved from http://ijpsat.ijsht-journals.org/index.php/ijpsat/article/view/539

Widyaningrum, D. A., \& Wijayanti, T. (2018). Developing of guided inquiry-based biochemistry practicum guidebook. JPBI (Jurnal Pendidikan Biologi Indonesia), 4(3), 209-214. doi: https://doi.org/10.22219/jpbi. v4i3.6857 